\title{
ASSET UTILIZATION EFFICIENCY AND OWNERSHIP STRUCTURE: \\ EVIDENCE FROM EMERGING AND DEVELOPING EASTERN EUROPE
}

\author{
Nurhan Aydin \\ Anadolu University, Eskişehir, Turkey \\ Gulsah Kulali \\ Anadolu University, Eskişehir, Turkey
}

\begin{abstract}
Does ownership structure have any effect on efficient use of company assets? If so, what are the ownership-related determinants of asset utilization efficiency? In this study we are seeking answers to these questions for firms operating in emerging and developing Eastern Europe. Our results support the view that ownership structure has a determinant role in efficient use of company assets. Main findings from our sample are as follows. Assets are used more efficiently in owner-managed firms than outsidermanaged firms both for large-sized companies and medium-sized companies. For large-sized companies, efficiency increases with the ownership share of executives and the controlling family ownership, while decreasing with the number of non-manager shareholders and the ownership share of non-manager block holders. For medium-sized companies, efficiency increases with the controlling family ownership.
\end{abstract}

Keywords: Asset Utilization Efficiency; Equity Agency Costs; Ownership Structure; Emerging and Developing Eastern European Companies

DOI: http://dx.doi.org/10.15549/jeecar.v5i1.186

\section{INTRODUCTION}

Does ownership structure have any effect on efficient use of company assets for firms operating in emerging and developing Eastern Europe? If so, what are the ownership-related determinants of asset utilization efficiency? The rationale for asking these questions is mainly based on Daily and Dalton's (1992) and Chrisman and Patel's (2012) arguments that ownership-based control has a significant impact on management, decision-making, and financial performance of firms. These research questions are also built on argument of
Gedajlovic et al. (2004), which states that problems that challenge firms, when becoming owner-managed to outsider-managed, are rooted in governance characteristics. These questions are also built on the literature addresses that the nature of agency conflicts varies among firms operating in different governance contexts (Gibson, 2003; Truong and Heaney, 2013; Gogineni et al., 2013; MullerKahle, 2015; Aras and Furtuna, 2015).

Existing literature has been seeking answers to these types of questions within sequentially expanding frameworks of equity agency 
conflicts, and corporate governance. Equity agency cost is a qualitative type of cost, and it is not reflected in financial statements as a cost item. It can only be quantified by using proxies. Asset utilization ratio (annual sales/total assets) is one of the most widely used inverse proxies for equity agency costs. It shows the loss in revenue per unit of investment that may be attributable to inefficient use of assets in companies. The low level of asset utilization ratio is considered to be the result of poor investment decisions such as investment in negative net present value projects, or failure to use assets productively. It is also associated with management shirking, or exerting insufficient effort.

Much of the past research about the relationship between asset utilization efficiency and ownership structure mostly focus on firms in advanced economies. Our research question instead, focuses on firms operating in emerging and developing Eastern Europe because they have specific ownership characteristics, which are different from widely studied sets of companies in the UK and the US.

We describe ownership characteristic differences in three dimensions. First, unlike US firms, many European firms except in UK, are controlled by few block holders who are also the board members (Barca and Becht, 2001). Second, control pyramids are highly common while family controlled assets constitute a large fraction of GDP in most of these countries. Evidence in empirical ownership structure studies shows that diffusely owned firms are less common outside the US and the UK (La Porta et al, 1999; Claessens et.al, 2000; Barca and Becht, 2001; Faccio and Lang, 2002; Young et al., 2008). Third, business groups are highly common structures in developing countries in Europe; even large block holders in the US conglomerates seldom control more than one corporation (Khanna and Palepu, 2000; Khanna et al., 2001; Morck et.al, 2005).

Main findings of our analysis support the view that ownership structure has a determinant role in efficient use of company assets. Analysis results for large-sized and medium-sized companies also reveal that owner-managed firms use company assets more efficiently than outsider-managed firms. For large-sized companies, we find that efficiency increases with the ownership share of executives and the controlling family ownership, while decreasing with the number of non-manager shareholders and the ownership share of non-manager block holders. For medium-sized companies, we find that efficiency only increases with the controlling family ownership.

This empirical paper has three contributions to equity agency conflicts literature. First, in conceptual terms, we contribute to extend understanding of how non-manager blockholders' monitoring and controlling roles may be different in different country contexts. Second, in empirical terms, we contribute to extend research of ownership structure and asset utilization efficiency beyond widely studied group of companies from the US and the UK, with more dispersed style of ownership. Third, in practical terms, this study adds to research regarding how ownership structure may be used to design tools for increasing firm value through increasing asset utilization efficiency.

\section{LITERATURE REVIEW}

The relationship between asset utilization efficiency and ownership structure may lead to a change in firm value, as is shown by much evidence in the literature (Morck et al., 1988; McConnell and Servaes, 1990; Han and Suk, 1998; Cui and Mak, 2002; Capozza and Seguin, 2003; Lins, 2003). Maximizing firm value as a main goal, it is worth it to invest in further empirical research on this relationship for companies in different institutional settings.

Scholars who use asset utilization ratio as an inverse proxy for equity agency costs (Ang et al., 2000; Singh and Davidson III, 2003; Fleming et al., 2005; Florackis and Ozkan, 2009; McKnight and Weir, 2009; Truong and Heaney, 2013) mostly base their research on Jensen and Meckling's (1976) zero-agency cost theory. According to this theory, a firm managed by a person who owns a hundred percent of the firm faces no equity agency cost. Since then, corporate governance has been serving as a good context when discussing agency conflicts.

Different perspectives are needed when dealing with issues related to corporate governance in developed economies with strong institutional contexts and in emerging economies with relatively weak institutional contexts (Khanna and Palepu, 1997; Dharwadkar et al., 2000; Young, 2008). Crittenden and Crittenden (2012) argue that corporate governance in emerging economies is 
under the influence of changing turbulent environmental factors, which are classified as demographic trends, technological development, natural resources, and political/legal unease. Also there is a lack of unique, suited governance models for firms based on individual properties of countries and firms (Black et al., 2010; Anderson and Gupta, 2013; Aras, 2015).

Along with different corporate governance and institutional contexts, some researchers also have looked closer at how equity agency costs, or its proxy, asset utilization efficiency, change with different ownership structures. Theoretically, Young et al., 2008 explain how agency costs differ among dispersed ownership and concentrated ownership structures. Tore (2017) argues that concentrated ownership gives rise to agency problems when a manager who has superior information acts on behalf of a group of shareholders while neglecting the others, and it requires a different set of solutions from state of dispersed ownership. On the other hand, empirically, for firms in Australia, Germany, UK, and US owner-managed firms and family-owned firms are found to be more efficient in asset utilization. Moreover, efficiency is reported to increase with managerial ownership, non-manager block ownership, and concentrated ownership in those countries (Fleming et al., 2005; Kaserer and Moldenhauer, 2008; Florackis and Ozkan, 2009; McKnight and Weir, 2009; Anand et al., 2009; Gogineni et al., 2013).

Among different ownership structures, managerial ownership has received special attention from researchers. Relationship between managerial ownership and equity agency costs has been widely studied especially for firms in US. Some papers report no relationship (Demsetz and Lehn, 1985 and Himmelberg et al., 1999; McMahon, 2004), some papers report linear relationship (Ang et al., 2000; Singh and Davidson III, 2003; Christoph and Moldenhauer, 2008), and some of them report a curvilinear relationship (Morck et al., 1988; McConnell and Servaes, 1990; Denis et al., 1997; Short and Keasey, 1999) between the two.

In conclusion, existing empirical studies conducted in various country settings have a general consensus that there is a relationship between ownership structure and efficiency in use of company assets. At the same time, the nature of this relationship seems to be highly dependent on industry, firm size, characteristics of ownership structure, country effects, and sample size. Apparently, asset utilization efficiency of firms in developing Eastern Europe has remained underexplored in comparison to firms in developed markets, which shows a need for further empirical evidence.

Combining the arguments in the existing theoretical and empirical literature, our hypotheses about the relationship between ownership structure and asset utilization efficiency for firms in developing Eastern Europe are as follows. H1: Ownership structure has effect on asset utilization ratio. H2: Asset utilization ratio is higher for owner-managed firms than outsider-managed firms. In relation to that, the number of non-manager shareholders has a negative effect on asset utilization ratio. H3: Ownership share of executives has a positive effect on asset utilization ratio. H4: Ownership share of nonmanager block-holders has an effect on asset utilization ratio. The direction of effect may either be positive or negative, depending on non-manager block-holders' approach. H5: Family ownership has a positive effect on asset utilization ratio.

\section{SAMPLE AND EMPIRICAL DESIGN}

\section{Sample Characteristics}

Our sample covers companies operating in net debtor emerging and developing economies in Eastern Europe, according to 2013 IMF World Economic Outlook Country Classification list. These countries are; Albania, Bosnia \& Herzegovina, Bulgaria, Croatia, Hungary, Kosovo, Lithuania, Macedonia, Montenegro, Poland, Romania, Serbia, and Turkey.

For consistency and variability, all firm-level financial and ownership data for 2013 is drawn from Orbis Database of Bureau Van Deijk, Germany. All companies in our sample are operating in non-financial industries according to Nace2 Rev. Industry Classification. The criteria for identification of firm size are presented in Appendix A, and filtering steps used are displayed in Appendix B. We do not drop certain percentages of maximum and minimum values from our sample to eliminate the effect of outliers because we have a significant number of companies wholly owned by executives, which means a zero-agency cost case of Jensen and Meckling (1976), which is 
important to include to our analysis. After data filtering and eliminations of missing data before conducting a formal analysis, our sample consists of 3.275 large-sized, and 9.006 medium-sized companies. The breakdown of number of companies by country is provided in Table 1, and the breakdown of number of companies by industry is provided in Table 2, Appendix C.

\section{Empirical Design}

We use the ratio of asset utilization efficiency as a validated inverse proxy for equity agency costs arising from conflicts between shareholders and managers. It constitutes the dependent variable in our analysis. We follow an empirical approach, which is similar to Ang et al. (2000), and estimate a linear model in order to explain how efficiency in asset utilization would change with the changes in ownership structure.

In order to examine ownership-related determinants of efficiency in asset utilization, we include four explanatory variables capturing various dimensions of the ownership structure. They are (i) ownership share of executives, (ii) the number of non-manager shareholders, (iii) an indicator for firms where a single individual or family controls minimum $50 \%$ of company shares, and (iv) ownership share of nonmanager block holders with minimum 5\% stake. In the existing literature, the percentage of total equity held by executives is used by Singh and Davidson III (2003); Fleming et al. (2005); Florackis and Ozkan (2009); Truong and Heaney (2013). The number of non-manager recorded shareholders is used by Ang et al. (2000), and Florackis and Ozkan (2009). Indicator for firms where one named individual or family have min. 50\% stake is used by Ang et al.(2000); Fleming et al. (2005). Percentages of total equity held by outside block holders is used by Singh and Davidson III (2003); Truong and Heaney (2013).

Three control variables which have been commonly used by firm-level empirical studies, are included in the analysis. These are: (i) firm size, (ii) leverage, and (iii) industry. Table 3 provides all variables used in the analysis with their definitions.

Descriptive statistics for the full sample of 3.275 large sized and 9.006 medium-sized, nonfinancial companies for 2013 are presented in Tables 4 and 5. Descriptive statistics show that remarkable aspects are the substance of equity held by executives, and non-manager block holders in medium-sized companies. Also, the difference between large sized and medium sized companies in terms of average numbers of non-manager shareholders is remarkable. These two instances, together with the medium-sized companies having lower agency costs (annual sales to total assets ratio of 1.6) than large-sized companies (annual sales to total assets ratio of 1.3), lead us expect a negative parameter coefficient of NON-MNGSHRH, and positive parameter coefficient of EQUITYEXECTV for large-sized companies in the regression equation with the dependent variable, annual sales/total assets.

Correlation coefficients calculated for two samples are presented in Table 6 and Table 7. Given these results, we do not expect multicolinearity to be a problem for the regression model fitted for the agency costs. For large-sized companies, correlation coefficients are typically smaller than 0.50 , which can be accepted as a rule of thumb (Truong and Heaney, 2013). For medium-sized companies, the same applies. Correlation coefficients are typically smaller than 0.50 . Only exceptions are the correlation between family ownership and equity held by executives for large-sized companies, and for the equity held by blockholders for medium-sized companies. This is totally acceptable to us because family members are also executives for some companies in our sample. Furthermore, some executive family members are also block-holders for some companies in medium-sized companies. Therefore, it would not be a problem for our model, as it is not caused by the variables themselves.

\section{Analysis Results}

\section{EMPIRICAL RESULTS}

In our sample, asset utilization ratio varies widely across manufacturing and nonmanufacturing industries, across firm sizes, and across leverage usage. Wide ranges point out the importance of controlling for these variables in the model of asset utilization efficiency, which we include to the linear regression model as control variables.

Figure 1 shows the ratio of annual sales/ total assets by manufacturing and nonmanufacturing industries, Figure 2 by below median-above median sales, and Figure 3 by 
below median-above median debt ratios. According to these three figures, average asset utilization ratio is higher for: i) nonmanufacturing industry companies than for manufacturing industry companies, ii) abovemedian sales companies than for below-median sales companies (We cannot be clear that it is because of high annual sales, or low total assets. For that reason, natural logarithm of sales is used to proxy for firm size, rather than sales quantity.), and iii) above median leveraged companies than for below-median leveraged companies, both for large-sized and mediumsized companies. Figure 3 also shows that medium-sized companies in our sample take the advantage of leverage in the form of a higher increase in the efficiency than large-sized companies. (It also appears in the regression results in Tables 9-10. The relationship between asset utilization ratio and leverage is positive and significant both for medium-sized companies, and large-sized companies.)
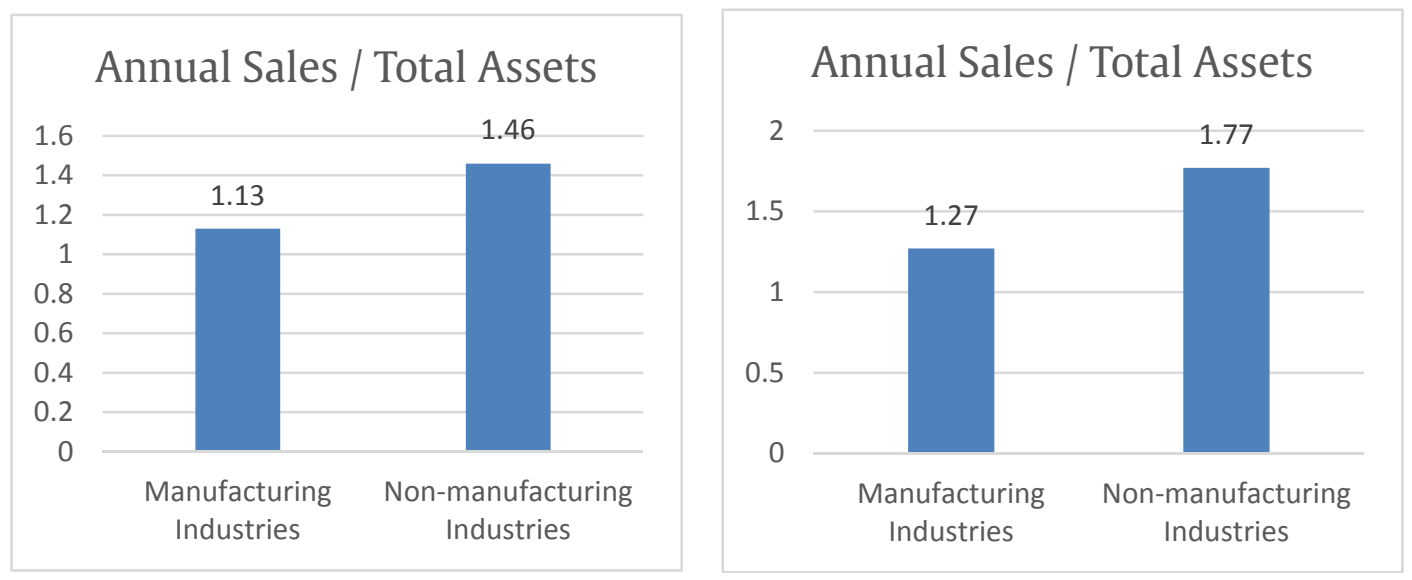

Figure 1. Asset Utilization Ratio by Industry for Large Companies (Panel A) and for Medium-Sized Companies (Panel B)
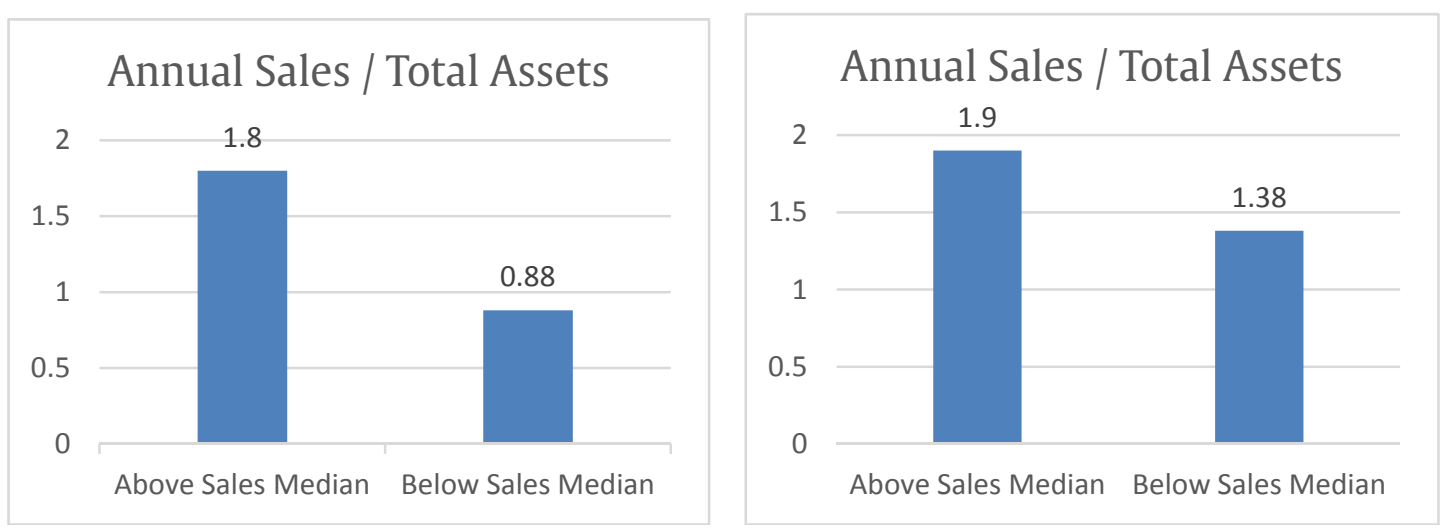

Figure 2. Asset Utilization Ratio by Sales for Large Companies (Panel A) and for Medium-Sized Companies (Panel B)

Following the approach of Ang et al. (2000), we also compare the agency costs for firms under two types of managers: owners and outsiders. This information is provided in Table 8. Both for large-sized and for medium-sized companies, asset utilization ratio is higher for firms that are owner-managed than firms that are outsider-managed. It supports the findings

of Jensen and Meckling (1976); Short and Keasey (1999); Ang et al. (2000); Singh and Davidson III (2003); Fleming et al. (2005); Florackis and Ozkan (2009); Gogineni et al. (2013); Muller-Kahle (2015).

Panel A of Table 8 shows annual sales/ total assets ratio for sample of all owner-managed large-sized 320 firms, and all outsider-managed 
large-sized 2955 firms. It also shows the ratio for the sample of all owner-managed 314 firms, and all outsider-managed 511 firms, where, at the same time, one or more individual family has minimum 50 percent stake in the company. It shows that most of (314 out of 320) ownermanagers are family owners for large-sized companies. For the full sample, average asset utilization ratio is higher for owner-managed firms (1.94) than outsider-managed firms (1.28). When one or more named individual family has at least 50 percent stake in the company, the asset utilization ratio still is greater for ownermanaged firms.

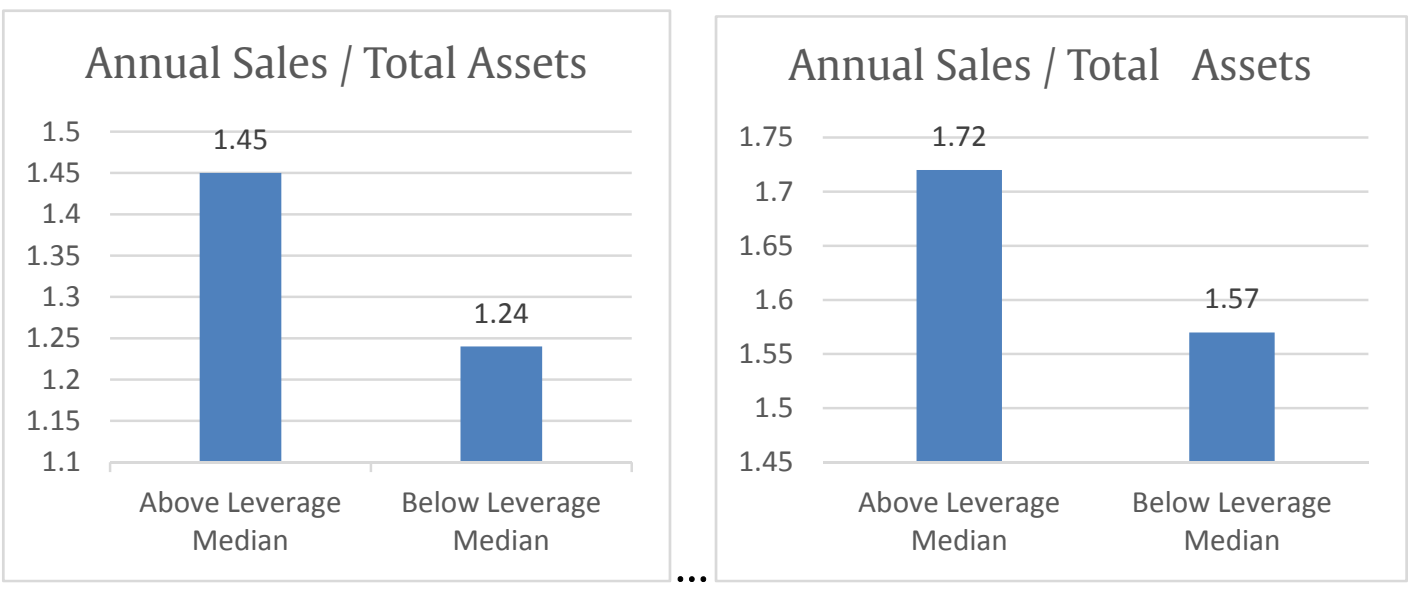

Figure 3. Asset Utilization Ratio by Leverage for Large Companies (Panel A) and for Medium-Sized Companies (Panel B)

Panel B of Table 8 shows same information for medium-sized companies. There is a sample of all owner-managed medium-sized 3151 firms, and all outsider-managed medium-sized 5855 firms. There is also a sample of all ownermanaged 3151 firms, and all outsider-managed 2363 firms, where, at the same time, one or more individual family has minimum 50 percent stake in the company. It shows that all of (3151 out of 3151) owner-managers are family owners for medium-sized companies. For the full sample, average asset utilization ratio is higher for owner-managed firms (1.68) than outsider-managed firms (1.62). When one or more named individual family has at least 50 percent stake in the company, the asset utilization ratio still is greater for ownermanaged firms.

\section{Estimation Results}

Tables 9 and 10 show the results we get from estimating linear regression equations for explaining the ownership-related determinants of annual sales / total assets for large sized and medium sized companies. Annual sales / total assets is regressed against four ownership variables (ownership share of executives, the number of non-manager shareholders, an indicator for firms where a single family controls minimum $50 \%$ of company shares, and ownership share of non-manager block holders with minimum 5\% stake), and three control variables (firm size, leverage, and industry). Five linear models are used to estimate whether ownership-related variables explain annual sales / total assets.

First columns of Table 9 and Table 10 identify the explanatory variables, and columns 2-6 present parameter estimates for different regression model specifications. In models 1-4, we include each of the ownership structure variables together with the control variables. In model 5, we include all four ownership structure variables, and control variables to our specification.

For large-sized companies, Model 1 shows that the coefficient of ownership share of the executives is positive and significant. And, Model 2 shows that the coefficient of the number of non-manager shareholders is negative and significant. These two findings support the view that giving some share to executives could decrease equity agency costs. Model 3, showing the effect of single family ownership on the asset utilization ratio, is 
positive and significant, supporting the view that equity conflicts are less when there is a controlling family ownership. Model 4 shows that the effect of ownership share of nonmanager block holders is negative and significant, suggesting that when the ownership is concentrated outside the firm, equity agency costs increase. In Model 5, each of the four ownership variables is significant.

For medium-sized companies, Model 1 and Model 2 show that asset utilization ratio does not change with change in the ownership share of the executives, or number of non-manager shareholders. These two evidences do not support the view that giving some share to executives could decrease agency costs. Model 3 shows the effect of single-family ownership on the asset utilization ratio is positive and significant. This finding supports the view that equity conflicts are less when there is a controlling family ownership. Model 4 shows that the asset utilization ratio does not change with the change in the ownership share of nonmanager block holders. In Model 5, each of the four ownership variables is significant.

Our findings support the findings of Ang et al. (2000) in a way that equity agency costs increase with the number of non-manager shareholders; Singh and Davidson III (2003) in a way that there is no significant relationship between equity agency costs and non-manager block ownership; Fleming et al. (2005) in a way that equity agency costs decrease with family ownership; and McKnight and Weir (2009) in a way that managerial ownership helps to reduce agency costs.

\section{DISCUSSION AND CONCLUSION}

Inefficient use of company assets is a concern to a varying degree for all companies. It is especially a challenging job to increase the efficiency for managers of companies operating in emerging and developing markets because of the common problems of those markets about corporate governance and institutional context in general.

In the framework of equity agency conflicts, asset utilization efficiency and ownership characteristics have been empirically studied widely at the firm level for developed markets, especially for firms from the US and the UK. It may also be considered as an interesting research theme for companies in emerging and developing Eastern Europe because their ownership structure characteristics are different from the ones operating in developed Europe, or other advanced economies of the world.

We can summarize our main findings in three sets of results. First, ownership structure has a determinant role in efficient use of company assets both for large-sized and medium-sized companies. Second, efficiency is higher for owner-managed firms than outsider-managed firms both for large-sized and medium-sized companies. These first two sets of results are consistent with, and supporting the results of existing empirical literature for companies in developed markets, where more dispersed ownership structure is common. However, our third set of results is more open to discussion, especially decrease in efficiency of non-manager block holders' shareholdings in large-sized companies.

Third set of results show that, on one hand, for large-sized companies, efficiency in asset utilization increases with the ownership share of executives and with the controlling family ownership, and decreases with the number of non-manager shareholders (which are consistent with existing evidence from literature) and with the ownership share of nonmanager block holders (can be unusual). On the other hand, for medium-sized companies, efficiency increases with the controlling family ownership, which is also aligned with our expectation from previous empirical studies.

For large-sized companies, a question mark is on non-manager block holders' shareholdings. It seems contrary to the general expectation we have from evidence for firms with dispersed ownership style. Because outside shareholders are considered to be good monitors, they are generally associated with low agency costs in the US and in other developed markets. Lins (2003) argues that they may be especially beneficial to minority shareholders if they help fill the external governance void in emerging markets. However, asset utilization efficiency decreases with the ownership share of nonmanager block holders for companies in our sample. There may be two ways to explain why. First, In US companies, non-manager block holders are typically investment funds, or angel investors whose goal is to benefit from increasing value of firm. They make real external pressure on the management to efficiently use company assets. However, in emerging and developing Eastern Europe, they 
are rather often banks, and institutional or private funds, which act in a more passive manner.

Second, as Muller-Kahle (2015) argues, it depends on the motivation of non-manager majority shareholders to control executives, and their capability of evaluating information about firms. Regarding the second reason, we think our estimation result indicates a transparency or a monitoring problem, on the transfer of timely, accurate, and enough data to nonmanager block holders. A solution to that problem can be achieved by better application of corporate governance principles. We think the key to success is the acknowledgement from the board of directors. Companies should have advice from internal auditors on compliance principles, by the support of board of directors. By this way, managers can incorporate these principles with the external pressure from nonmanager block holders to use company assets in a more efficient way.

Overall, this paper has three contributions to agency conflicts literature. First, in conceptual terms, we contribute to extend understanding of how non-manager block-holders' monitoring and controlling roles may be different in different country contexts. Second, in empirical terms, we contribute to extend research of ownership structure and asset utilization efficiency beyond widely studied group of companies from the US and the UK, with more dispersed style of ownership. Third, in practical terms, this study adds to research regarding how ownership structure may be used to design tools for increasing firm value through increasing asset utilization efficiency.

In terms of limitations, we have limits for this study, which may be primarily common for researchers studying empirically at firm level in developing countries. Common problems are related to standardization, reliability, and enough data for fulfilment of analysis needs. In the empirical analysis of this study, our sample is limited to companies listed in Orbis database. There may be a number of companies meeting our criteria, but they could not be included in our analysis. This limits generalizability of our results. Second, even though our dependent variable, asset utilization ratio, is a validated proxy for equity agency costs, there is another proxy, using operating expenses as a base, which we could not use because most of the data was not available, especially for medium- sized companies. This limits robustness of our analysis results. Nevertheless, this study provides a reliable set of information about ownership-related determinants of asset utilization ratio with the substantial data, aiming at contributing to the knowledge of equity agency conflicts in emerging and developing Eastern European markets.

For further research on asset utilization efficiency issues in developing Europe, we think family ownership deserves extra attention for medium-sized companies. Furthermore, understanding will be more complemented with the use of corporate governance explanatory variables (e.g. CEO tenure, board size, number of outside members on the board, CEO duality), which we could not reach for this study.

\section{Acknowledgements:}

An earlier version of this paper was presented in the 7th International Research Meeting in Business and Management (IRMBAM-2016), IPAG Business School, France.

\section{REFERENCES}

Anand, A., Milne, F., and Purda, L. (2009), Monitoring to Reduce Agency Costs: Examining the Behavior of Independent and Non-Independent Boards. Seattle UL Rev., 33, 809.

Anderson, A. M. and Gupta, P. P. (2013), "Corporate Governance: Does One Size Fit All?", Journal of Corporate Accounting \& Finance, 24(3), 51-64.

Ang, J. S., Cole, R. A., and Lin, J. W. (2000), "Agency costs and ownership structure", The Journal of Finance, 55(1), 81-106.

Aras, G. (2015), “The Effect of Corporate Governance Practices on Financial Structure in Emerging Markets: Evidence from BRICK Countries and Lessons for Turkey", Emerging Markets Finance and Trade, 51(2), 5-24.

Aras, G. and Kutlu Furtuna, O. (2015), “Does governance efficiency affect equity agency costs? Evidence from Borsa Istanbul", Emerging Markets Finance and Trade, 51(2), 84-100.

Barca, F. and Becht, M. (2001), The Control Of Corporate Europe, Oxford: Oxford University Press. 
Black, B. S., de Carvalho, A. G., and Gorga, É. (2010), "Does one size fit all in corporate governance? Evidence from Brazil (and other BRIK Countries)", ECGI Law Working Paper, No. 30.

Capozza, D. R. and Seguin, P. J. (2003), “Inside Ownership, Risk Sharing and Tobin's Q Ratios: Evidence from REITs", Real Estate Economics, 31(3), 367-404.

Chrisman, J. J. and Patel, P. J. (2012) "Variations in R\&D investments of family and nonfamily firms: Behavioral agency and myopic loss aversion perspectives", Academy of Management Journal, 55(4), 976-997.

Christoph, K. and Moldenhauer, B. (2008), "Insider ownership and corporate performance: evidence from Germany", Review of Managerial Science, 2(1), 1-35.

Claessens, S., Djankov, S., and Lang, L. H. (2000), "The separation of ownership and control in East Asian corporations", Journal of Financial Economics, 58(1), 81-112.

Crittenden, V. L. and Crittenden, W. F. (2012), "Corporate governance in emerging economies: understanding the game", Business Horizons, 55(6), 567-574.

Cui, H. and Mak, Y. T. (2002), "The relationship between managerial ownership and firm performance in high R\&D firms", Journal of Corporate Finance, 8(4), 313-336.

Daily C. M. and Dalton, D. R. (1992), "Financial performance of founder-managed versus professionally managed small corporations", Journal of Small Business Management, 30, 25-34.

Dharwadkar, R., George, G. and Brandes, P. (2000). "Privatization in emerging economies: an agency theory perspective", Academy of Management Review, 25, 65069.

Demsetz, H. and Lehn, K. (1985), "The structure of corporate ownership: Causes and consequences", Journal of Political Economy, 93(6), 1155-1177.

Denis, D. J., Denis, D. K., and Sarin, A. (1997), "Agency problems, equity ownership, and corporate diversification", The Journal of Finance, 52(1), 135-160.

Faccio, M., and Lang, L. H. (2002), "The ultimate ownership of Western European corporations", Journal of Financial Economics, 65(3), 365-395.
Fleming, G., Heaney, R., and McCosker, R. (2005), "Agency costs and ownership structure in Australia", Pacific-Basin Finance Journal, 13(1), 29-52.

Florackis, C. and Ozkan, A. (2009), "The impact of managerial entrenchment on agency costs: An empirical investigation using UK panel data", European Financial Management, 15(3), 497-528.

Gedajlovic, E. R., Lubatkin, M. H. and Schulze, W. S. (2004), "Crossing the threshold from founder management to professional management: a governance perspective", Journal of Management Studies, 41, 988-12.

Gibson, M. (2003), "Is corporate governance ineffective in emerging markets?", The Journal of Financial and Quantitative Analysis, 38(1), 231-250.

Gogineni, S., Linn, S. C., and Yadav, P. K. (2013), "Ownership structure, management control and agency costs", College of Business, University of Wyoming, Laramie WY, 82072.

Han, K. C. and Suk, D. Y. (1998), "The effect of ownership structure on firm performance: Additional evidence", Review of Financial Economics, 7(2), 143-155.

Himmelberg, C. P., Hubbard, R. G., and Palia, D. (1999), "Understanding the determinants of managerial ownership and the link between ownership and performance", Journal of Financial Economics, 53(3), 353-384.

Jensen, M. C. and Meckling, W. H. (1976), "Theory of the firm: Managerial behavior, agency costs and ownership structure", Journal of Financial Economics, 3(4), 305360.

Kaserer, C. and Moldenhauer, B. (2008), “Insider ownership and corporate performance: evidence from Germany", Review of Managerial Science, 2(1), 1-35.

Khanna, T. and Palepu, K. (1997), "Why focused strategies may be wrong for emerging markets", Harward Business Review, July 1 1997.

Khanna, T. and Palepu, K. (2000), "Is group affiliation profitable in emerging markets? An analysis of diversified Indian business groups", The Journal of Finance, 55(2), 867891.

Khanna, T., Kogan, J., and Palepu, K. G. (2001), Globalization and Corporate Governance Convergence?: A Cross-country Analysis, 
Division of Research, Harvard Business School.

La Porta, R., Lopez-de-Silanes, F., Shleifer, A., and Vishny, R. (1999), "The quality of government", Journal of Law, Economics, and Organization, 15(1), 222-279.

Lins, K. V. (2003). "Equity ownership and firm value in emerging markets" Journal of Financial and Quantitative Analysis, 38(1), 159-184.

McConnell, J. J. and Servaes, H. (1990), "Additional evidence on equity ownership and corporate value", Journal of Financial Economics, 27(2), 595-612.

McMahon, R. G. (2004), "Equity agency costs amongst manufacturing SMEs", Small Business Economics, 22(2), 121-140.

McKnight, P. J. and Weir, C. (2009), "Agency costs, corporate governance mechanisms and ownership structure in large UK publicly quoted companies: A panel data analysis", The Quarterly Review of Economics and Finance, 49(2), 139-158.

Morck, R., Shleifer, A. and Vishny, R. W. (1988), "Management ownership and market valuation: An empirical analysis", Journal of Financial Economics, 20, 293-315.

Morck, R., Wolfenzon, D., and Yeung, B. (2005), "Corporate governance, economic entrenchment, and growth", Journal of Economic Literature, 43(3), 655-720.

Muller-Kahle, M. I. (2015), "The impact of dominant ownership: the case of AngloAmerican firms", Journal of Management \& Governance, 19(1), 71-89.

Short, H. and Keasey, K. (1999), “Managerial Ownership and the Performance of Firms: Evidence from the UK", Journal of Corporate Finance, 5(1), 79-101.
Singh, M. and Davidson III, W. N. (2003), "Agency costs, ownership structure and corporate governance mechanisms", Journal of Banking \& Finance, 27(5), 793-816.

Tore, I. (2017), "Rethinking Agency Theory in Companies with Concentrated Ownership", International Journal of Business and Management Studies, 9(1), 80-91.

Truong, T. T. and Heaney, R. (2013), "The determinants of equity agency conflicts between managers and shareholders: Evidence from Australia", Journal of Multinational Financial Management, 23(4), 314-326.

Young, M., Peng, M., Ahlstrom, D., Bruton, G. and Jiang, Y. (2008), "Corporate Governance in Emerging Economies: A Review of the Principal-Principal Perspective", Journal of Management Studies, 45(1), 196-220.

\section{ABOUT THE AUTHORS}

Nurhan Aydin, email: naydin@anadolu.edu.tr

Dr. Nurhan Aydin is working as a professor at Anadolu University, Turkey. She is in the Business Administration Department at Faculty of Economics and Administrative Sciences. Her research interests include financial management and international business finance, specifically mergers \& acquisitions and investment decisions.

Dr. Gulsah Kulali is working as an assistant professor at Anadolu University, Turkey. She is in the Business Administration Department at Faculty of Economics and Administrative Sciences. Her research interests include corporate finance and international business finance, particularly foreign direct investments and ownership structure. 
Appendix A. Company Size Category Definitions

\section{Large companies}

Companies are considered to be large when they match at least one of the following conditions:

- Operating Revenue $>=10$ million EUR (13 million USD)

- Total assets $>=20$ million EUR (26 million USD)

- Employees $>=150$

\section{Notes:}

- Companies with ratios Operating Revenue per Employee or Total Assets per Employee below 100 EUR (130 USD) are excluded from this category.

- Companies for which Operating Revenue, Total Assets and Employees are unknown but have a level of Capital comprised between 500 thousand EUR (650 thousand USD) and 5 million EUR (6.5 million USD) are also included in the category.

\section{Medium sized companies}

Companies are considered to be medium sized when they match at least one of the following conditions:

- Operating Revenue $>=1$ million EUR (1.3 million USD)

- Total assets $>=2$ million EUR (2.6 million USD)

- Employees $>=15$

- Not Large

Notes:

- Companies with ratios Operating Revenue per Employee or Total Assets per Employee below 100 EUR (130 USD) are excluded from this category.

- Companies for which Operating Revenue, Total Assets and Employees are unknown but have a level of Capital comprised between 50 thousand EUR (65 thousand USD) and 500 thousand EUR (650 thousand USD) are also included in the category. 
Appendix B. Summary of Data Filtering

\begin{tabular}{|c|c|c|c|c|c|}
\hline \multirow[b]{2}{*}{ Steps } & \multirow[b]{2}{*}{ Search Criteria } & \multicolumn{2}{|c|}{ Large Sized Companies } & \multicolumn{2}{|c|}{ Medium Sized Companies } \\
\hline & & Step result & $\begin{array}{l}\text { Search } \\
\text { result }\end{array}$ & Step result & $\begin{array}{l}\text { Search } \\
\text { result }\end{array}$ \\
\hline 1. & $\begin{array}{l}\text { All active companies and } \\
\text { companies with unknown } \\
\text { situation }\end{array}$ & $114,707,917$ & $114,707,917$ & $114,689,710$ & $114,689,710$ \\
\hline 2. & $\begin{array}{l}\text { World region/Country/Region in } \\
\text { country: Albania, Bosnia and } \\
\text { Herzegovina, Bulgaria, Croatia, } \\
\text { Hungary, Kosovo, Lithuania, } \\
\text { Macedonia, Montenegro, Poland, } \\
\text { Romania, Serbia, Turkey }\end{array}$ & $7,751,678$ & $6,173,504$ & $7,751,115$ & $6,176,199$ \\
\hline 3. & $\begin{array}{l}\text { Type of entities: Industrial } \\
\text { companies }\end{array}$ & $123,095,482$ & $5,829,157$ & $123,118,394$ & $5,933,313$ \\
\hline 4. & $\begin{array}{l}\text { Category of companies: A. Large } \\
\text { (medium-sized) companies, } \\
\text { active with recent detailed } \\
\text { financials }\end{array}$ & 791,920 & 31,472 & $2,646,049$ & 163,890 \\
\hline 5. & $\begin{array}{l}\text { Operating revenue (Turnover): } \\
\text { All companies with a known } \\
\text { value, 2013, 2012, 2011, 2010, } \\
2009,2008,2007,2006,2005 \text {, } \\
2004 \text {, for all the selected periods }\end{array}$ & 874,051 & 7,038 & 852,288 & 29,795 \\
\hline 6. & $\begin{array}{l}\text { P/L for period [=Net income]: All } \\
\text { companies with a known value, } \\
2013,2012,2011,2010,2009, \\
2008,2007,2006,2005,2004, \\
\text { for all the selected periods }\end{array}$ & 870,465 & 6,647 & 828,768 & 9,840 \\
\hline 7. & $\begin{array}{l}\text { EBITDA: All companies with a } \\
\text { known value, 2013, 2012, 2011, } \\
2010,2009,2008,2007,2006 \text {, } \\
\text { 2005, 2004, for all the selected } \\
\text { periods }\end{array}$ & 489,922 & 3,407 & 449,991 & 9,834 \\
\hline & \multicolumn{3}{|c|}{ Boolean search : 1 And 2 And 3 And 4 And 5 And 6 And 7} & & \\
\hline & & TOTAL & 3,407 & TOTAL & 9,834 \\
\hline
\end{tabular}

Note: Only companies providing active financial data for operating revenue, profit/loss, and EBITDA (earnings before interest, tax, depreciation and amortization) are included. With these criteria, we reach a sample of 3.407 large sized, and 9.834 medium-sized companies. In Orbis, country filter, industry filter, and company size filter are used. 


\section{Appendix C}

Table 1. Country Breakdown of Companies in the Sample

\begin{tabular}{|c|c|c|c|}
\hline \multicolumn{2}{|l|}{ Large-sized Companies } & \multicolumn{2}{|l|}{ Medium-sized Companies } \\
\hline Bosnia and Herzegovina & 348 & Bosnia and Herzegovina & 831 \\
\hline Bulgaria & 65 & Bulgaria & 63 \\
\hline Croatia & 786 & Croatia & 3808 \\
\hline Hungary & 378 & Hungary & 415 \\
\hline Lithuania & 18 & Macedonia & 1 \\
\hline Poland & 268 & Poland & 333 \\
\hline Romania & 3 & Serbia and Montenegro & 3555 \\
\hline Serbia and Montenegro & 1305 & & \\
\hline Turkey & 104 & & \\
\hline Total & 3275 & Total & 9006 \\
\hline
\end{tabular}

Note: i) There is no available data for companies in Albania and Kosovo in the database, matching our search criteria. ii) Companies in large-sized and medium-sized classes are considered as two separate groups. We do not make comparisons within each group. This is the reason why we do not eliminate Romania with 3 companies in Panel A, and Macedonia with one company in Panel B.

Table 2 Industry Breakdown of Companies in the Sample

\begin{tabular}{|lll|}
\hline NACE Rev. 2 Industry Main Section & \multicolumn{1}{c|}{$\begin{array}{l}\text { Large-Sized } \\
\text { Companies }\end{array}$} & $\begin{array}{l}\text { Medium-Sized } \\
\text { Companies }\end{array}$ \\
\hline Accommodation and food service activities & 92 & 186 \\
Administrative and support service activities & 70 & 174 \\
Agriculture, forestry and fishing & 141 & 367 \\
Arts, entertainment and recreation & 19 & 47 \\
Construction & 255 & 835 \\
Education & 29 & 52 \\
Electricity, gas, steam and air conditioning supply & 71 & 29 \\
Human health and social work activities & 27 & 80 \\
Information and communication & 99 & 251 \\
Manufacturing & 1174 & 2306 \\
Mining and quarrying & 32 & 53 \\
Professional, scientific and technical activities & 125 & 567 \\
Public administration and defense; compulsory social security & 4 & 5 \\
Transportation and storage & 154 & 491 \\
Water supply; sewerage, waste management and remediation & 138 & 146 \\
activities & & \\
Wholesale and retail trade; repair of motor vehicles and & 832 & 3358 \\
motorcycles & 13 & 59 \\
Other service activities & 3275 & 9006 \\
Total & & \\
\hline
\end{tabular}


Table 3. Summary of the variables used in the analysis

\begin{tabular}{|l|l|}
\hline AGENCYCOSTS & Annual sales / Total assets \\
\hline EQUITYEXECTV & Percentage of total equity held by executives \\
\hline NON-MNGSHRH & $\begin{array}{l}\text { The number of non-manager recorded shareholders } \\
\text { FAMILY }\end{array}$ \\
\hline EQUITYBLOCK & $\begin{array}{l}\text { Percentage of total equity held by non-manager block holders with min. } \\
5 \% \text { stake }\end{array}$ \\
\hline FIRMSIZE & Log (annual sales) \\
\hline LEVERAGE & Total debt/ Total assets \\
\hline MANUF & Indicator for firms where Nace.2.Rev. industry is `manufacturing \\
\hline
\end{tabular}

Note: i) Industry is classified into two, as manufacturing and non-manufacturing, and MANUF is used as a binary variable. If the company is operating in a manufacturing industry it takes ' 1 ', If it operates in a non-manufacturing industry it takes ' 0 '. ii) Non-manager block holders have min.5\% stake in the company, and at the same time they are not managers in the company.

Table 4. Descriptive Statistics for Large-sized Companies

The variables for a sample of 3275 large-sized companies appear in the first column. In columns 2-6, sample means and medians, maximum and minimum values, and standard deviations appear.

\begin{tabular}{|c|c|c|c|c|c|}
\hline & Mean & Median & Max. & Min. & $\begin{array}{l}\text { Std. } \\
\text { Dev. }\end{array}$ \\
\hline \multicolumn{6}{|l|}{ Agency Costs Variable } \\
\hline AGENCYCOST (Annual sales/ Total assets) & 1.34 & 0.98 & 31.01 & 0.00 & 1.59 \\
\hline \multicolumn{6}{|l|}{ Ownership Structure Variables } \\
\hline & 18.42 & 0.00 & 100 & 0.00 & 34.43 \\
\hline \multicolumn{6}{|l|}{$\begin{array}{l}\text { EQUITYEXECTV (Percentage of total equity held by } \\
\text { executives) }\end{array}$} \\
\hline $\begin{array}{l}\text { NON-MNGSHRH (The number of non-manager } \\
\text { recorded shareholders) }\end{array}$ & 4.23 & 1.00 & 733.00 & 0.00 & 16.65 \\
\hline $\begin{array}{l}\text { FAMILY (Indicator for firms where one named } \\
\text { individual or family have min. } 50 \% \text { stake) }\end{array}$ & 0.25 & 0.00 & 1.00 & 0.00 & 0.43 \\
\hline $\begin{array}{l}\text { EQUITYBLOCK (Percentage of total equity held by } \\
\text { non-manager block holders with min. } 5 \% \text { stake) }\end{array}$ & 3.04 & 0.00 & 100.00 & 0.00 & 16.41 \\
\hline \multicolumn{6}{|l|}{ Control Variables } \\
\hline FIRMSIZE (Log of annual sales) & 4.09 & 4.23 & 7.58 & -0.98 & 1.03 \\
\hline LEVERAGE (Total debt/ Total assets) & 57.56 & 58.51 & 100.00 & 0.23 & 27.96 \\
\hline $\begin{array}{l}\text { MANUF (Indicator for firms where Nace.2.Rev. } \\
\text { industry is 'manufacturing") }\end{array}$ & 0.36 & 0.00 & 1.00 & 0.00 & 0.48 \\
\hline No. of observations & 3275 & 3275 & 3275 & 3275 & 3275 \\
\hline
\end{tabular}


Table 5. Descriptive Statistics for Medium-sized Companies

The variables for a sample of 9006 medium-sized companies appear in the first column. In columns 26 , sample means and medians, maximum and minimum values, and standard deviations appear.

\begin{tabular}{|c|c|c|c|c|c|}
\hline & Mean & Median & Max. & Min. & Std.Dev. \\
\hline Agency Costs Variable & & & & & \\
\hline AGENCYCOST (Annual sales/ Total assets) & 1.64 & 1.26 & 55.87 & 0.00 & 1.84 \\
\hline Ownership Structure Variables & & & & & \\
\hline $\begin{array}{r}\text { EQUITYEXECTV (Percentage of total equity held by } \\
\text { executives) }\end{array}$ & 41.98 & 0.00 & 100.00 & 0.00 & 46.60 \\
\hline $\begin{array}{l}\text { NON-MNGSHRH (The number of non-manager recorded } \\
\text { shareholders) }\end{array}$ & 1.55 & 1.00 & 133.00 & 0.00 & 5.53 \\
\hline $\begin{array}{l}\text { FAMILY (Indicator for firms where one named individual or } \\
\text { family have min. } 50 \% \text { stake) }\end{array}$ & 0.61 & 1.00 & 1.00 & 0.00 & 0.49 \\
\hline $\begin{array}{l}\text { EQUITYBLOCK (Percentage of total equity held by non- } \\
\text { manager block holders with min. } 5 \% \text { stake) }\end{array}$ & 74.65 & 100.00 & 100.00 & 0.00 & 42.91 \\
\hline \multicolumn{6}{|l|}{ Control Variables } \\
\hline FIRMSIZE (Log of annual sales) & 3.30 & 3.32 & 4.14 & -0.76 & 0.47 \\
\hline LEVERAGE (Total debt/ Total assets) & 53.39 & 54.37 & 100.00 & 0.05 & 26.44 \\
\hline $\begin{array}{l}\text { MANUF (Indicator for firms where Nace.2.Rev. industry is } \\
\text { 'manufacturing') }\end{array}$ & 0.06 & 0.00 & 1.00 & 0.00 & 0.44 \\
\hline No. of observations & 9006 & 9006 & 9006 & 9006 & 9006 \\
\hline
\end{tabular}

Table 6. Correlation Coefficients, Large-sized Companies

The variables for a sample of 3275 large-sized companies appear in the first column. Covariance and correlation coefficient appear in columns 2-8.

\begin{tabular}{|c|c|c|c|c|c|c|c|c|}
\hline $\begin{array}{l}\text { Covariance } \\
\text { Correlation }\end{array}$ & FIRMSIZE & MANUF & FAMILY & $\begin{array}{l}\text { EQUITY } \\
\text { EXECTV }\end{array}$ & LEVERAGE & $\begin{array}{l}\text { NON- } \\
\text { MNGSHRH }\end{array}$ & $\begin{array}{l}\text { EQUITY } \\
\text { BLOCK }\end{array}$ & $\begin{array}{l}\text { AGENCY } \\
\text { COSTS }\end{array}$ \\
\hline FIRMSIZE & $\begin{array}{l}0.224644 \\
1\end{array}$ & & & & & & & \\
\hline MANUF & $\begin{array}{l}-0.00522 \\
-0.02523\end{array}$ & $\begin{array}{l}0.190489 \\
1\end{array}$ & & & & & & \\
\hline FAMILY & $\begin{array}{l}0.014745 \\
0.06385\end{array}$ & $\begin{array}{l}0.01134 \\
0.053328\end{array}$ & $\begin{array}{l}0.237398 \\
1\end{array}$ & & & & & \\
\hline EQUITYEXECTV & $\begin{array}{l}1.446006 \\
0.06547\end{array}$ & $\begin{array}{l}0.801847 \\
0.039426\end{array}$ & $\begin{array}{l}16.27665 \\
0.716884\end{array}$ & $\begin{array}{l}2171.476 \\
1\end{array}$ & & & & \\
\hline LEVERAGE & $\begin{array}{l}-0.07783 \\
-0.00621\end{array}$ & $\begin{array}{l}-0.61291 \\
-0.05312\end{array}$ & $\begin{array}{l}-0.61433 \\
-0.04769\end{array}$ & $\begin{array}{l}-1.45196 \\
-0.00118\end{array}$ & $\begin{array}{l}698.8894 \\
1\end{array}$ & & & \\
\hline $\begin{array}{l}\text { NON- } \\
\text { MNGSHRH }\end{array}$ & $\begin{array}{l}-0.06736 \\
-0.0257\end{array}$ & $\begin{array}{l}-0.05047 \\
-0.02091\end{array}$ & $\begin{array}{l}-0.07646 \\
-0.02837\end{array}$ & $\begin{array}{l}-48.5603 \\
-0.18842\end{array}$ & $\begin{array}{l}-8.08149 \\
-0.05527\end{array}$ & $\begin{array}{l}30.58966 \\
1\end{array}$ & & \\
\hline EQUITYBLOCK & $\begin{array}{l}0.656471 \\
0.032276\end{array}$ & $\begin{array}{l}0.722623 \\
0.038583\end{array}$ & $\begin{array}{l}14.43229 \\
0.690259\end{array}$ & $\begin{array}{l}1046.4 \\
0.523282\end{array}$ & $\begin{array}{l}25.97113 \\
0.022893\end{array}$ & $\begin{array}{l}-41.234 \\
-0.17373\end{array}$ & $\begin{array}{l}1841.489 \\
1\end{array}$ & \\
\hline AGENCYCOSTS & $\begin{array}{l}0.167178 \\
0.192015\end{array}$ & $\begin{array}{l}-0.09617 \\
-0.11995\end{array}$ & $\begin{array}{l}0.033109 \\
0.036992\end{array}$ & $\begin{array}{l}1.678118 \\
0.019604\end{array}$ & $\begin{array}{l}1.919783 \\
0.039532\end{array}$ & $\begin{array}{l}-0.15063 \\
-0.01483\end{array}$ & $\begin{array}{l}0.462891 \\
0.005872\end{array}$ & $\begin{array}{l}3.374369 \\
1\end{array}$ \\
\hline
\end{tabular}


Table 7. Correlation Coefficients, Medium-sized Companies

The variables for a sample of 9006 medium-sized companies appear in the first column. Covariance and correlation coefficient appear in columns 2-8.

\begin{tabular}{|c|c|c|c|c|c|c|c|c|}
\hline $\begin{array}{l}\text { Covariance } \\
\text { Correlation }\end{array}$ & FIRMSIZE & MANUF & FAMILY & $\begin{array}{l}\text { EQUITY } \\
\text { EXECTV }\end{array}$ & LEVERAGE & $\begin{array}{c}\text { NON- } \\
\quad \text { MNGS } \\
\text { HRH } \\
\end{array}$ & $\begin{array}{l}\text { EQUITY } \\
\text { BLOCK }\end{array}$ & $\begin{array}{l}\text { AGENCY } \\
\text { COSTS }\end{array}$ \\
\hline FIRMSIZE & $\begin{array}{l}1.054798 \\
1\end{array}$ & & & & & & & \\
\hline MANUF & $\begin{array}{l}0.044705 \\
0.09077\end{array}$ & $\begin{array}{l}0.22997 \\
1\end{array}$ & & & & & & \\
\hline FAMILY & $\begin{array}{l}-0.0565 \\
-0.12672\end{array}$ & $\begin{array}{l}-0.01091 \\
-0.05242\end{array}$ & $\begin{array}{l}0.188451 \\
1\end{array}$ & & & & & \\
\hline EQUITYEXECTV & $\begin{array}{l}-2.26299 \\
-0.06401\end{array}$ & $\begin{array}{l}-0.6178 \\
-0.03743\end{array}$ & $\begin{array}{l}10.17385 \\
0.680827\end{array}$ & $\begin{array}{l}1184.948 \\
1\end{array}$ & & & & \\
\hline LEVERAGE & $\begin{array}{l}2.28035 \\
0.07943\end{array}$ & $\begin{array}{l}0.185124 \\
0.01381\end{array}$ & $\begin{array}{l}0.373003 \\
0.030738\end{array}$ & $\begin{array}{l}-11.6761 \\
-0.01213\end{array}$ & $\begin{array}{l}781.3809 \\
1\end{array}$ & & & \\
\hline NON-MNGSHRH & $\begin{array}{l}-1.2686 \\
-0.07419\end{array}$ & $\begin{array}{l}0.05027 \\
0.006296\end{array}$ & $\begin{array}{l}-0.40357 \\
-0.05584\end{array}$ & $\begin{array}{l}-28.1997 \\
-0.0492\end{array}$ & $\begin{array}{l}-6.29663 \\
-0.01353\end{array}$ & $\begin{array}{l}277.2092 \\
1\end{array}$ & & \\
\hline EQUITYBLOCK & $\begin{array}{l}5.174605 \\
0.307007\end{array}$ & $\begin{array}{l}0.066094 \\
0.008398\end{array}$ & $\begin{array}{l}-0.54494 \\
-0.07649\end{array}$ & $\begin{array}{l}-34.0211 \\
-0.06022\end{array}$ & $\begin{array}{l}1.780007 \\
0.00388\end{array}$ & $\begin{array}{l}6.56693 \\
0.024033\end{array}$ & $\begin{array}{l}269.3331 \\
1\end{array}$ & \\
\hline AGENCYCOSTS & $\begin{array}{l}0.53585 \\
0.328923\end{array}$ & $\begin{array}{l}-0.07688 \\
-0.10107\end{array}$ & $\begin{array}{l}0.040253 \\
0.058457\end{array}$ & $\begin{array}{l}4.568241 \\
0.083663\end{array}$ & $\begin{array}{l}2.429323 \\
0.054788\end{array}$ & $\begin{array}{l}-2.07318 \\
-0.0785\end{array}$ & $\begin{array}{l}1.625282 \\
0.062434\end{array}$ & $\begin{array}{l}2.516109 \\
1\end{array}$ \\
\hline
\end{tabular}

Table 8. Asset Utilization Efficiency for Owner- managed Firms and Outsider-managed Firms

Agency costs are shown for a sample of 3275 large-sized, and 9006 medium-sized companies. There are two groups of firms as owner-managed and outsider-managed. Owner-managed firms are those in which total equity held by executives is 100 percent. Outsider- managed firms are those in which total equity held by executives is smaller than 100 percent. Last column of each panel shows the difference between ratios of the owner-managed and the outsider-managed firms.

\begin{tabular}{|c|c|c|c|c|c|}
\hline & \multicolumn{5}{|c|}{ Type of Manager } \\
\hline & \multicolumn{2}{|c|}{ Owner-Manager } & \multicolumn{2}{|c|}{ Outsider-Manager } & \multirow{2}{*}{$\begin{array}{l}\text { Difference } \\
\text { In Means } \\
\text { (In Median) }\end{array}$} \\
\hline & $\begin{array}{l}\text { Number of } \\
\text { Firms }\end{array}$ & $\begin{array}{l}\text { Ratio Mean } \\
\text { (Median) }\end{array}$ & $\begin{array}{l}\text { Number } \\
\text { of Firms }\end{array}$ & $\begin{array}{l}\text { Ratio Mean } \\
\text { (Median) }\end{array}$ & \\
\hline \multicolumn{6}{|c|}{ Panel A: Annual sales / Total Assets Ratio, Large Sized Companies } \\
\hline All firms & 320 & $1.94(1.60)$ & 2955 & $1.28(0.91)$ & $0.66(0.69)$ \\
\hline $\begin{array}{l}\text { One named } \\
\text { individual or family } \\
\text { have min. } 50 \% \text { stake }\end{array}$ & 314 & $1.95(1.60)$ & 511 & $1.23(0.86)$ & $0.72(0.74)$ \\
\hline \multicolumn{6}{|c|}{ Panel B: Annual sales / Total Assets Ratio, Medium Sized Companies } \\
\hline All firms & 3151 & $1.68(1.31)$ & 5855 & $1.62(1.23)$ & $0.06(0.08)$ \\
\hline $\begin{array}{l}\text { One named individual } \\
\text { or family have min. } \\
50 \% \text { stake }\end{array}$ & 3151 & $1.68(1.31)$ & 2363 & $1.72(1.28)$ & $-0.04(0.03)$ \\
\hline
\end{tabular}


Table 9. Estimation of Model Specification for Large-sized Companies

Dependent variable is annual sales / total assets, which is an inverse proxy for equity agency costs. There are four explanatory variables: ownership share of executives, number of non-manager shareholders, an indicator for firms where a single family controls minimum 50\% of company shares, ownership share of non-manager block holders with minimum $5 \%$ stake. There are three control variables: Log of annual sales, Total debt / Total assets, an indicator for firms where Nace.2.Rev. industry is `manufacturing`.

\begin{tabular}{|c|c|c|c|c|c|}
\hline Intercept & $\begin{array}{l}\text { Model } 1 \\
-0.865^{* * * *} \\
(-7.37) \\
\end{array}$ & $\begin{array}{l}\text { Model } 2 \\
-0.688^{* * * *} \\
(-5.89) \\
\end{array}$ & $\begin{array}{l}\text { Model } 3 \\
-0.890^{* * * *} \\
(-7.51) \\
\end{array}$ & $\begin{array}{l}\text { Model } 4 \\
-0.805^{* * * *} \\
(-6.76) \\
\end{array}$ & $\begin{array}{l}\text { Model } 5 \\
-0.915^{* * * *} \\
(-7.5)\end{array}$ \\
\hline $\begin{array}{l}\text { Ownership Structure Variables } \\
\text { EQUITYEXECTV (Percentage of } \\
\text { total equity held by } \\
\text { executives) }\end{array}$ & $\begin{array}{l}0.004^{* * * *} \\
(6.22)\end{array}$ & & & & $\begin{array}{l}0.003^{* * *} \\
(3.0)\end{array}$ \\
\hline $\begin{array}{l}\text { NON-MNGSHRH (The number of } \\
\text { non-manager recorded } \\
\text { shareholders) }\end{array}$ & & $\begin{array}{l}-0.005^{* * *} \\
(-3.20)\end{array}$ & & & $\begin{array}{l}-0.004^{* * *} \\
(-2.7)\end{array}$ \\
\hline $\begin{array}{l}\text { FAMILY (Indicator for firms } \\
\text { where one named individual } \\
\text { or family have min. 50\% } \\
\text { stake) }\end{array}$ & & & $\begin{array}{l}0.348^{* * * *} \\
(5.81)\end{array}$ & & $\begin{array}{l}0.166^{* *} \\
(2.0)\end{array}$ \\
\hline $\begin{array}{l}\text { EQUITYBLOCK (Percentage of } \\
\text { total equity held by non- } \\
\text { manager block holders with } \\
\text { min. } 5 \% \text { stake) }\end{array}$ & & & & $\begin{array}{l}-0.004^{* * *} \\
(-2.61)\end{array}$ & $\begin{array}{l}-0.004^{* *} \\
(-2.2)\end{array}$ \\
\hline Control Variables & & & & & \\
\hline FIRMSIZE (Log of annual sales) & $\begin{array}{l}0.532^{* * * *} \\
(21.02)\end{array}$ & $\begin{array}{l}0.517^{* * * *} \\
(20.30)\end{array}$ & $\begin{array}{l}0.542^{* * * *} \\
(21.24)\end{array}$ & $\begin{array}{l}0.544^{* * * *} \\
(20.39)\end{array}$ & $\begin{array}{l}0.551^{* * * *} \\
(20.6)\end{array}$ \\
\hline $\begin{array}{r}\text { LEVERAGE (Total debt/ Total } \\
\text { assets) }\end{array}$ & $\begin{array}{l}0.002^{*} \\
(1.87)\end{array}$ & $\begin{array}{l}0.002^{*} \\
(1.79)\end{array}$ & $\begin{array}{l}0.001 \\
(1.58)\end{array}$ & $\begin{array}{l}0.002^{*} \\
(1.76)\end{array}$ & $\begin{array}{l}0.002^{*} \\
(1.7)\end{array}$ \\
\hline $\begin{array}{l}\text { MANUF (Indicator for firms } \\
\text { where Nace.2.Rev. industry } \\
\text { is 'manufacturing') }\end{array}$ & $\begin{array}{l}-0.427^{* * * *} \\
(-7.90)\end{array}$ & $\begin{array}{l}-0.435^{* * * *} \\
(-8.02)\end{array}$ & $\begin{array}{l}-0.424^{* * * *} \\
(-7.85)\end{array}$ & $\begin{array}{l}-0.440^{* * * *} \\
(-8.12)\end{array}$ & $\begin{array}{l}-0.425^{* * * *} \\
(-7.9)\end{array}$ \\
\hline Regression Statistics & & & & & \\
\hline Adjusted R square & 0.135 & 0.128 & 0.134 & 0.127 & 0.139 \\
\hline F-statistic & $129.29^{* * * *}$ & $121.17^{* * * *}$ & $127.88^{* * * *}$ & $120.18^{* * * *}$ & $76.69 * * * *$ \\
\hline No. of observations & 3275 & 3275 & 3275 & 3275 & 3275 \\
\hline
\end{tabular}

${ }^{* * * *} \mathrm{p}<0.001,{ }^{* * *} \mathrm{p}<0.01,{ }^{* *} \mathrm{p}<0.05,{ }^{*} \mathrm{p}<0.10$. 
Table 10. Estimation of Model Specification for Medium-sized Companies

Dependent variable is annual sales / total assets, which is an inverse proxy for equity agency costs. There are four explanatory variables: ownership share of executives, number of non-manager shareholders, an indicator for firms where a single family controls minimum 50\% of company shares, ownership share of non-manager block holders with minimum $5 \%$ stake. There are three control variables: Log of annual sales, Total debt / Total assets, an indicator for firms where Nace.2.Rev. industry is `manufacturing`.

\begin{tabular}{|c|c|c|c|c|c|}
\hline Intercept & $\begin{array}{l}\text { Model } 1 \\
-0.797^{* * * *} \\
(-5.72) \\
\end{array}$ & $\begin{array}{l}\text { Model } 2 \\
-0.777^{* * * *} \\
(-5.56) \\
\end{array}$ & $\begin{array}{l}\text { Model } 3 \\
-0.840^{* * * *} \\
(-6.00) \\
\end{array}$ & $\begin{array}{l}\text { Model } 4 \\
-0.797^{* * * *} \\
(-5.62) \\
\end{array}$ & $\begin{array}{l}\text { Model } 5 \\
-0.765^{* * * *} \\
(-5.36) \\
\end{array}$ \\
\hline $\begin{array}{l}\text { Ownership Structure Variables } \\
\text { EQUITYEXECTV (Percentage of } \\
\text { total equity held by } \\
\text { executives) }\end{array}$ & $\begin{array}{l}0.000 \\
(1.14)\end{array}$ & & & & $\begin{array}{l}-0.001^{*} \\
(-1.9)\end{array}$ \\
\hline $\begin{array}{l}\text { NON-MNGSHRH (The number of } \\
\text { non-manager } \\
\text { shareholders) }\end{array}$ & & $\begin{array}{l}-0.003 \\
(-1.02)\end{array}$ & & & $\begin{array}{l}-0.007^{*} \\
(-1.9)\end{array}$ \\
\hline $\begin{array}{l}\text { FAMILY (Indicator for firms where } \\
\text { one named individual or } \\
\text { family have min. } 50 \% \text { stake) }\end{array}$ & & & $\begin{array}{l}0.124^{* * *} \\
(3.19)\end{array}$ & & $\begin{array}{l}0.308^{* * * *} \\
(4.55)\end{array}$ \\
\hline $\begin{array}{l}\text { EQUITYBLOCK (Percentage of } \\
\text { total equity held by non- } \\
\text { manager block holders with } \\
\text { min. } 5 \% \text { stake) }\end{array}$ & & & & $\begin{array}{l}0.000 \\
(0.33)\end{array}$ & $\begin{array}{l}-0.002^{* * *} \\
(-2.86)\end{array}$ \\
\hline Control Variables & & & & & \\
\hline FIRMSIZE (Log of annual sales) & $\begin{array}{l}0.731^{* * * *} \\
(18.32)\end{array}$ & $\begin{array}{l}0.733^{* * * *} \\
(18.41)\end{array}$ & $\begin{array}{l}0.726^{* * * *} \\
(18.20)\end{array}$ & $\begin{array}{l}0.734^{* * * *} \\
(18.42)\end{array}$ & $\begin{array}{l}0.724^{* * * *} \\
(18.16)\end{array}$ \\
\hline $\begin{array}{r}\begin{array}{r}\text { LEVERAGE } \\
\text { assets })\end{array} \\
\text { Total debt/ Total }\end{array}$ & $\begin{array}{l}0.002^{* * * *} \\
(3.37)\end{array}$ & $\begin{array}{l}0.002^{* * * *} \\
(3.31)\end{array}$ & $\begin{array}{l}0.003^{* * * *} \\
(3.51)\end{array}$ & $\begin{array}{l}0.002^{* * * *} \\
(3.36)\end{array}$ & $\begin{array}{l}0.003^{* * * *} \\
(3.70)\end{array}$ \\
\hline $\begin{array}{l}\text { MANUF (Indicator for firms } \\
\text { where Nace.2.Rev. industry is } \\
\text { manufacturing }\end{array}$ & $-0.479^{* * * *}$ & $-0.478^{* * * *}$ & $-0.484^{* * * *}$ & $0.478^{* * * *}$ & $-0.485^{* * * *}$ \\
\hline Regression Statistics & & & & & \\
\hline Adjusted R square & 0.051 & 0.051 & 0.052 & 0.051 & 0.053 \\
\hline F-statistic & $122.09^{* * * *}$ & $122.02^{* * * *}$ & $124.43^{* * * *}$ & $121.77^{* * * *}$ & $72.99^{* * * *}$ \\
\hline No. of observations & 9006 & 9006 & 9006 & 9006 & 9006 \\
\hline
\end{tabular}

${ }^{* * * *} \mathrm{p}<0.001,{ }^{* * *} \mathrm{p}<0.01,{ }^{* *} \mathrm{p}<0.05,{ }^{*} \mathrm{p}<0.10$. 